\title{
Quantifying Wedge-Ice Volumes in Yedoma and Thermokarst Basin Deposits
}

Mathias Ulrich, Guido Grosse, Jens Strauss and Lutz Schirrmeister

Article first published online: 4 JUN 2014

DOI: $10.1002 /$ ppp.1810

Copyright @ 2014 John Wiley \& Sons, Ltd.

View Full Article with Supporting Information (HTML)

Enhanced Article (HTML)

Get PDF (913K)

Keywords:

- permafrost;

- ground ice;

- polygonal networks;

- GIS;

- remote sensing;

- Arctic

\begin{abstract}
Wedge-ice volume (WIV) is a key factor in assessing the response of ice-rich permafrost landscapes to thaw and in quantifying deep permafrost soil carbon inventories. Here, we present a method for calculating WIV in late Pleistocene Yedoma deposits and Holocene thermokarst basin deposits at four study areas in Siberia and Alaska. Ice-wedge polygons and thermokarst mound (baydzherakh) patterns were mapped on different landscape units using very high-resolution ( $0.5 \mathrm{~m} / \mathrm{pixel}$ ) satellite imagery (WorldView-1 and GeoEye-1). In a geographic information system (GIS) environment, Thiessen polygons were automatically created to reconstruct relict ice-wedge polygonal networks, and field and published data on ice-wedge dimensions were used to generate three-dimensional subsurface models that distinguish between epi- and syngenetic ice-wedge geometry. The results reveal significant variations in WIV between the study sites and within certain terrain units. Calculated maximum WIV ranges from 31.4 to 63.2 vol\% for Yedoma deposits and from 6.6 to 13.2 vol\% for thermokarst basin deposits.
\end{abstract}

Copyright @ 2014 John Wiley \& Sons, Ltd. 